\title{
К ВОПРОСУ О ТРАНСФОРМАЦИИ СИСТЕМЫ ВЫСШЕГО ОБРАЗОВАНИЯ
}

\author{
(C) 2020 Окороков Алексей Владимирович \\ заместитель директора Курского техникума экономики и управления, \\ аспирант Юго-Западного государственного университета, Россия, Курск \\ E-mail: okorokoff@gmail.com
}

В статье рассматриваются трансформационные процессы в системе высшего образования России, произошедшие с 1993 года. Обосновывается необходимость изменений требований к выпускникам вуза, их способности извлекать, преобразовывать, перераспределять знания в добавленную стоимость, увеличивающую возврат на капитал. Высшее учебное заведение, как и все субъекты рыночной экономики, ощущает на себе влияние сил несовершенной конкуренции. Должны изыскиваться новые, эффективные пути трансформации системы высшего образования, организации современного вузовского менеджмента, вноситься изменения, направленные на функционирование не только в сегодняшнем, но и в завтрашнем дне.

Ключевые слова: общество знаний, экономика знаний, изменения, конкурентоспособность, когнитивный капитализм, несовершенная конкуренция, трансформация, НООК.

Система высшего образования помогает России отвечать на вызовы, стоящие в социальной и экономической сферах, обеспечении национальной безопасности, переходе организаций и отраслей на новые формы хозяйствования, в том числе, используя достижения технологической и «цифровой революции». Человеческий потенциал и качество человеческого капитала, опора на образованность общества были и остаются главными слагаемыми успеха высших учебных заведений страны. Они обеспечивают реализацию научно-педагогического, учебно-методического, организационного, правового, финансово-экономического, кадрового, материально-технического потенциала системы высшего образования в форме инновационных проектов и программ организаций, осуществляющих образовательную деятельность [9, ст.20].

Россия обладает на мировой арене уникальными конкурентными преимуществами в сфере развития креативных индустрий. «Мир стремительно меняется, и экономика из ресурсной превращается в экономику знаний и экономику креатива <...> Хорошая новость заключается в том, что это изменение экономики - это блестящая возможность для России, потому что с точки зрения креатива, таланта, творчества нам точно не надо никого догонять - 100\%», заявил первый заместитель руководителя администрации президента Сергей Кириенко. По его словам, тысячелетняя история России, уникальное культурное, национальное и географическое разнообразие «становятся конкурентными преимуществами», если это суметь правильно использовать [3].

Первым ввел понятие «общество знаний» П. Друкер. Определяется «общество знаний» как экономика, в которой производство, распределение и применение знаний становятся главными драйверами экономического роста, создания добавленной стоимости и новых рабочих мест [2]. Поэтому, «экономика знаний» логично увязывается с задачами развития информационных и телекоммуникационных технологий, инноваций и изменений как внутри самих вузов, так и в целом в вузовском сообществе, зачастую выходя за его пределы в социальное пространство.

Общество и экономика знаний формируют новые требования к высшим учебным заведениям по подготовке кадров. Будущее предприятия, отрасли и страны зависит от того, насколько выпускник вуза способен извлекать, преобразовывать, перераспределять знания в добавленную стоимость, увеличивающую возврат на капитал. Это так называемый «когнитивный капитализм», построенный по распределенному принципу [1].

На новые запросы общества по подготовке высокопрофессиональных кадров и изменения образовательной повестки, российское высшее образование откликнулось, в соответствии с ФЗ «Об образовании», разделением вузов на ка- 
тегории. В настоящее время, высшие учебные заведения России имеют статусы (категории): федеральных университетов (10 вузов), национальных исследовательских университетов (29 вузов).

Два старейших ведущих классических университета - Московский государственный (МГУ) и Санкт-Петербургский государственный (СПбГУ) - выделяются Федеральным Законом в отдельную категорию [9]. Оба университета обладают особыми правами, являясь примером не только для отечественного, но и зарубежного высшего образования, ректоры этих вузов отчитываются об итогах своей работы лично перед Президентом страны.

Совет по реализации программ развития опорных университетов Министерства науки и образования России определил 33 региональных университета со статусом «опорный университет». Опорные вузы ориентированы на поддержку развития субъекта Российской Федерации посредством обеспечения местного рынка труда высококвалифицированными специалистами, решение актуальных задач региональной экономики и реализацию совместно с регионом и его предприятиями образовательных и инновационных проектов. Опорные вузы появились с начала 2016 года [4].

Остальные 616 высших учебных заведений (почти 90\% от общего числа) имеют статус «университет, академия, институт».
Следует учесть, что в соответствии со статьёй 22, п.4 Ф3 «Об образовании» [9], образовательная организация является либо государственной, либо муниципальной или частной. Закон уточняет, что решение принимается учредителем, а это означает формирование его ответственности за эффективное функционирование учебного заведения, включая финансирование реализации основных образовательных программ и поддержки обучающихся.

Всего в России функционирует 741 вуз, в том числе 496 государственных и 245 - частных [5]. Диаграмма 1 отражает динамику изменения количества российских вузов на протяжении последнего столетия.

В системе высшего образования России работают свыше 236 тыс. чел. профессорскопреподавательского состава (без внешних совместителей), которые обеспечивают знаниями, умениями и навыками более 4,0 млн. студентов бакалавриата, специалитета и магистратуры. В пересчете на 10000 населения число студентов составляет 284 человека [8]. Статистические данные и иллюстрации к ним (таблица 1, рисунки $1,2,3)$ показывают динамику этих изменений.

Динамические ряды данных о ППС и обучающихся студентах показывают, что ситуация в высшем образовании России подвержена колебаниям: от резкого увеличения количества вузов (2000-2011 годы), студентов (2005-2011 годы) и преподавателей в них (2005-2011 годы), к бы-

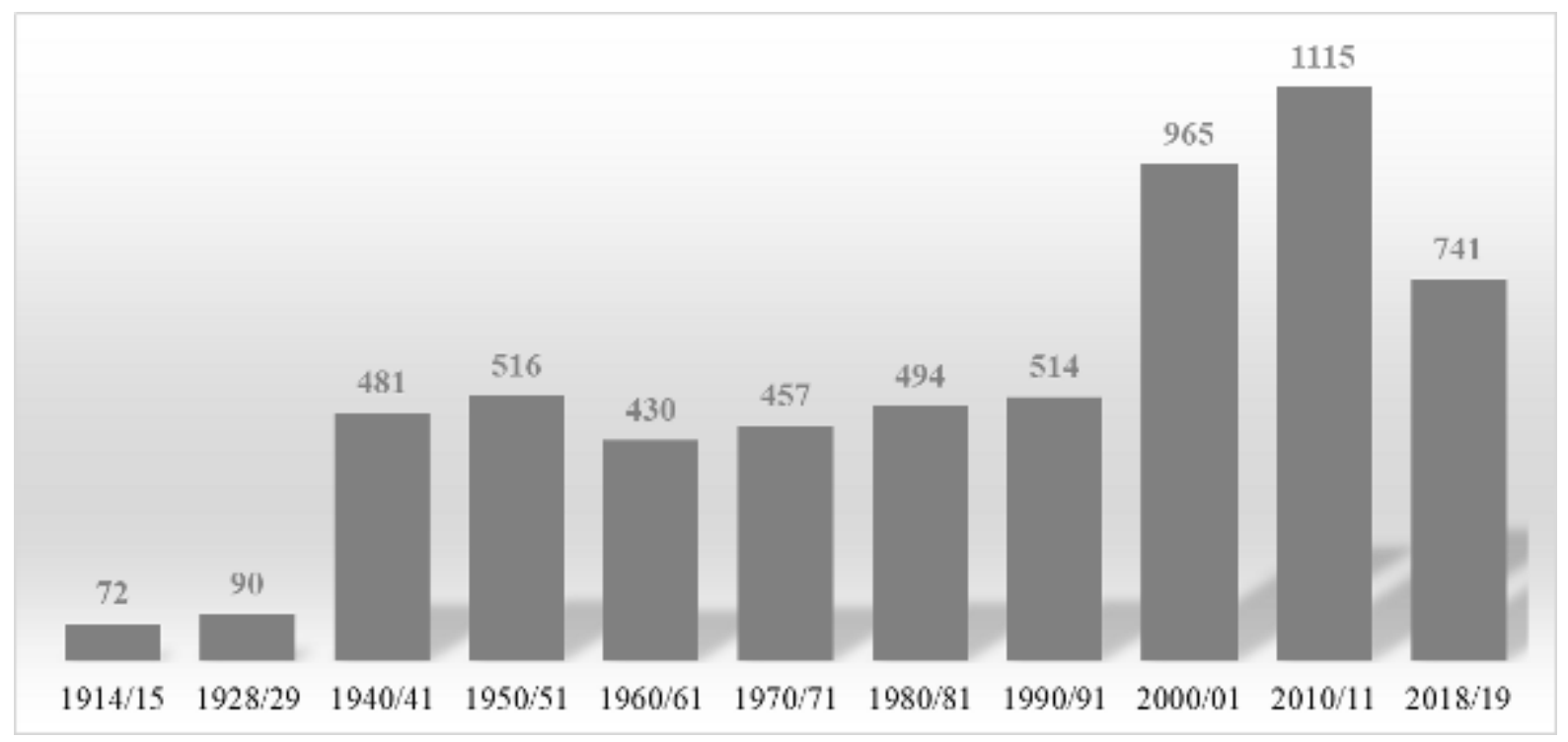

Диаграмма 1. Динамика количества вузов в Российской Федерации. Источник: составлено по данным ЦСУ РСФСР, Росстата. Источник https://yakapitalist.ru/finansy/skolko-v-rossii-vuzov-v-2019-g/ [5]. 
Таблица 1. Изменение численности студентов и ППС в 1993-2019 уч. годах

\begin{tabular}{|l|c|c|c|c|c|c|c|c|c|}
\hline \multicolumn{1}{|c|}{ Изменение численности студентов и ППС в 1993-2019 гг. } \\
\hline \multicolumn{1}{|c|}{ Учебный год } & $\begin{array}{c}1993 / \\
1994\end{array}$ & $\begin{array}{c}2000 / \\
2001\end{array}$ & $\begin{array}{c}2005 / \\
2006\end{array}$ & $\begin{array}{c}2010 / \\
2011\end{array}$ & $\begin{array}{c}2014 / \\
2015\end{array}$ & $\begin{array}{c}2015 / \\
2016\end{array}$ & $\begin{array}{c}2016 / \\
2017\end{array}$ & $\begin{array}{c}2017 / \\
2018\end{array}$ & $\begin{array}{c}2018 / \\
2019\end{array}$ \\
\hline $\begin{array}{l}\text { Численность студентов, } \\
\text { тыс. чел. }\end{array}$ & 2613,0 & 4741,4 & 7064,6 & 7049,8 & 5209,0 & 4766,5 & 4399,5 & 4245,9 & 4161,7 \\
\hline в т.ч. женщин & 1347,0 & 2686,3 & 4113,8 & 4030,1 & 2812,7 & 2548,6 & 2358,4 & 2279,6 & 2225,6 \\
\hline $\begin{array}{l}\text { \% студентов женского } \\
\text { пола }\end{array}$ & $51,5 \%$ & $56,7 \%$ & $58,2 \%$ & $57,2 \%$ & $54,0 \%$ & $53,5 \%$ & $53,6 \%$ & $53,7 \%$ & $53,5 \%$ \\
\hline $\begin{array}{l}\text { Численность ППС (без } \\
\text { внешних совместите- } \\
\text { лей), тыс. чел. }\end{array}$ & 243,6 & 307,4 & 387,3 & 356,8 & 299,7 & 279,7 & 261,0 & 245,1 & 236,1 \\
\hline $\begin{array}{l}\text { Отношение числа сту- } \\
\text { дентов к числу препода- } \\
\text { вателей }\end{array}$ & 10,7 & 15,4 & 18,2 & 19,8 & 17,4 & 17,0 & 16,9 & 17,3 & 17,6 \\
\hline $\begin{array}{l}\text { Численность студентов } \\
\text { на 10 тыс. населения }\end{array}$ & 176 & 324 & 493 & 493 & 356 & 325 & 300 & 289 & 284 \\
\hline
\end{tabular}

Источник: Россия в цифрах. 2019: Крат.стат.сб./Росстат- М., 2019-549 с. [8].

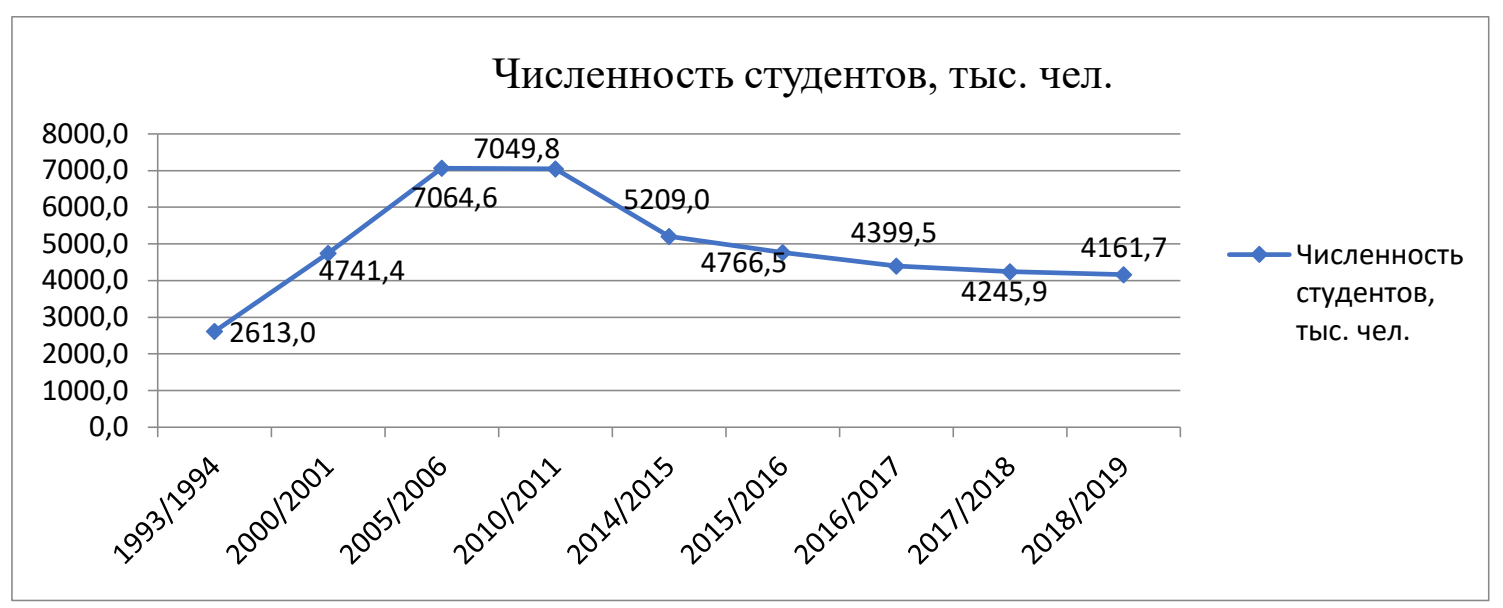

Рисунок 1. Динамика изменения численности студентов в 1993-2019 уч. годах. Выполнено автором

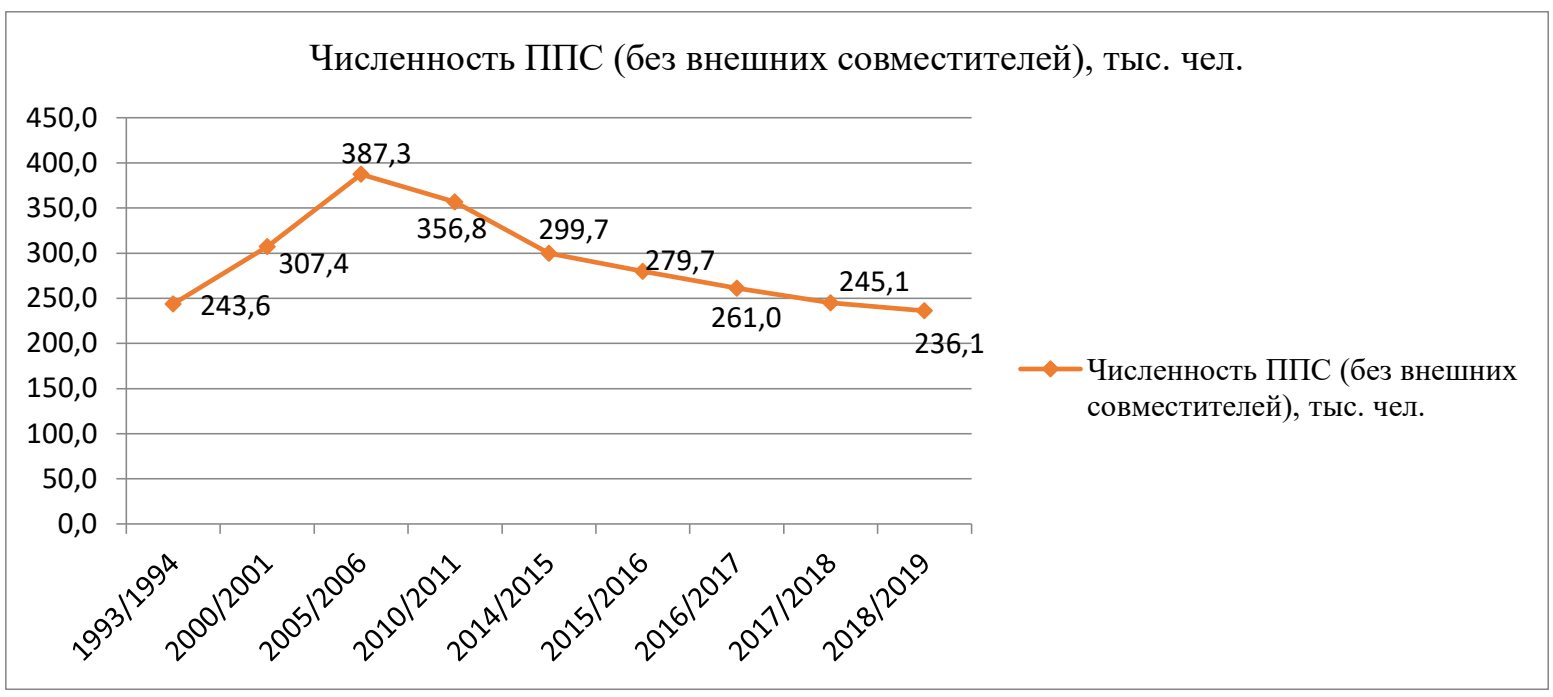

Рисунок 2. Динамика изменения численности ППС (без внешних совместителей) в 1993-2019 уч. годах. Выполнено автором 


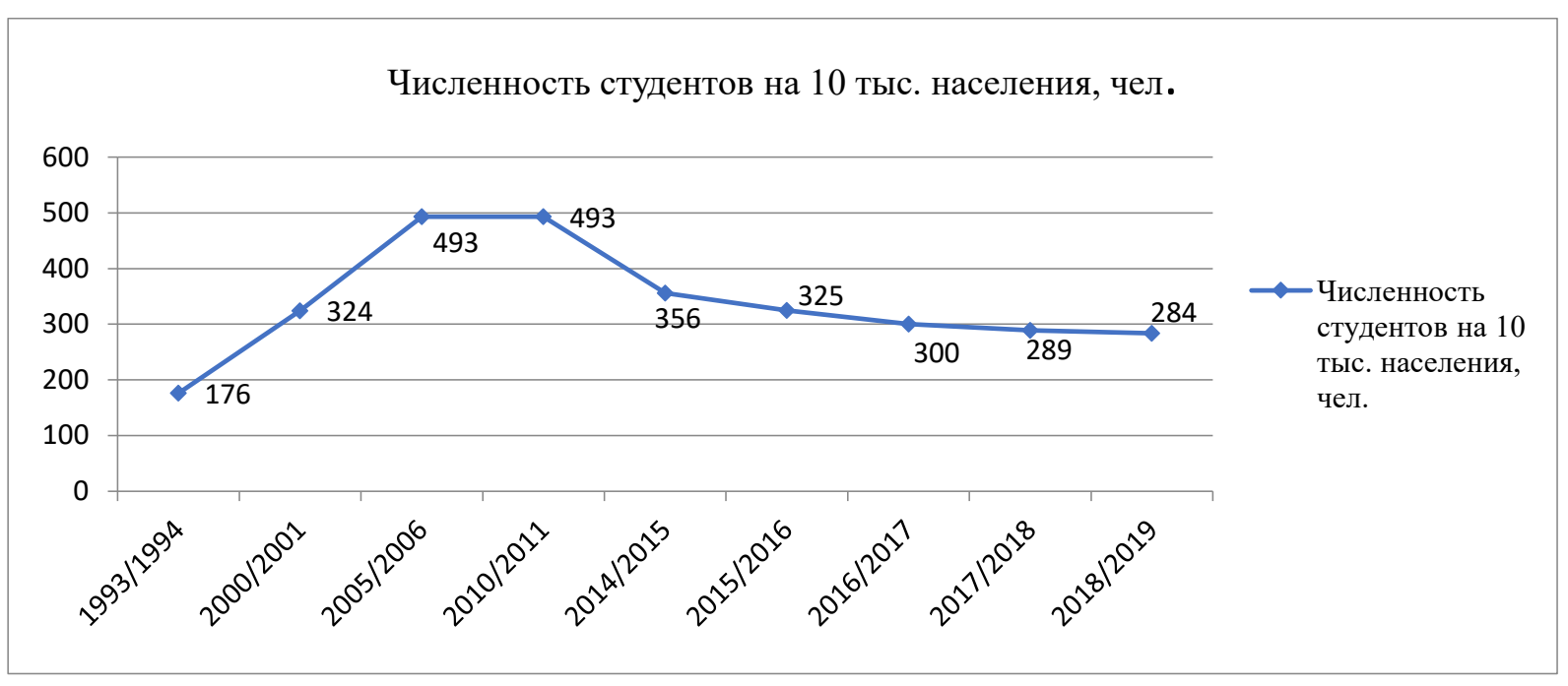

Рисунок 3. Динамика изменения численности студентов на 10 тыс. населения. Выполнено автором

строму уменьшению основных показателей, начиная с 2011 года.

Такие же тенденции демонстрируют данные о приеме на обучение и выпуске бакалавров, специалистов и магистров. За последние 25 лет самый большой прием студентов приходится на 2005 год - 1млн. 640 тыс. студентов. Самый большой выпуск - в 2010 году - 1 млн. 467 тыс. выпускников. На 2010 год приходится и самое большое количество выпускников в расчете на 10000 населения - 217 чел., в 2018 году этот показатель составил только 129 человек. Статистические данные и рисунки к ним (табл. 2, рис. $4,5,6$,$) наглядно иллюстрируют информацию о$ приеме в вузы и выпуске, начиная с 1993 года.

Приведенный статистический обзор и анализ решений Министерства образования и науки в области высшей школы подводит к мысли о том, что эпоха реорганизации и закрытия вузов подходит к завершению. Это подтверждают руководители системы высшего образования: «В рамках действующей модели проводятся плановые и внеплановые проверки. В дальнейшем предлагается развивать не столько проверки, сколько профилактику, предупреждение воз- можных нарушений. Следует уйти от воздействия на всю образовательную организацию в целом и перейти к точечному воздействию на тех лиц, которые допустили те или иные нарушения, которые привели к той или иной ситуации» [7].

В ответственности вузов остаются вопросы набора студентов и слушателей, преподавателей - для обеспечение учебно-воспитательного процесса. В современных условиях высшее учебное заведение, как и все субъекты рыночной экономики, ощущает на себе влияние сил несовершенной конкуренции. МГУ и СПбГУ, федеральные университеты, национальные исследовательские университеты, опорные университеты, используя определения экономической теории, действуют, скорее, в рамках монополии или олигополии. А самый массовый сектор, вузы со статусом «университет, академия, институт» находятся под влиянием монополистической конкуренции. Следовательно, согласно постулатам экономической теории, именно здесь, в первую очередь, должны изыскиваться новые, эффективные пути организации и управления высшими учебными заведениями, вноситься

Таблица 2. Динамика изменений числа принятых и выпущенных студентов в 1993-2018 гг.

\begin{tabular}{|l|c|c|c|c|c|c|c|c|c|}
\hline \multicolumn{2}{|c|}{ Динамика изменений числа принятых и выпущенных студентов в 1993-2018 гг. } \\
\hline \multicolumn{1}{|c|}{ год } & 1993 & 2000 & 2005 & 2010 & 2014 & 2015 & 2016 & 2017 & 2018 \\
\hline Принято студентов, тыс. чел. & 590,0 & 1292,5 & 1640,0 & 1399,5 & 1191,7 & 1221,8 & 1157,8 & 1142,0 & 1147,9 \\
\hline Выпущено студентов, тыс. чел. & 445,0 & 635,1 & 1151,0 & 1467,9 & 1226,0 & 1300,5 & 1161,1 & 969,5 & 933,2 \\
\hline Выпуск студентов на 10 тыс. населения & 63 & 99 & 172 & 217 & 171 & 180 & 160 & 134 & 129 \\
\hline
\end{tabular}

Источник: Россия в цифрах. 2019: Крат.стат.сб./Росстат- М., 2019-549 с. [8]. 


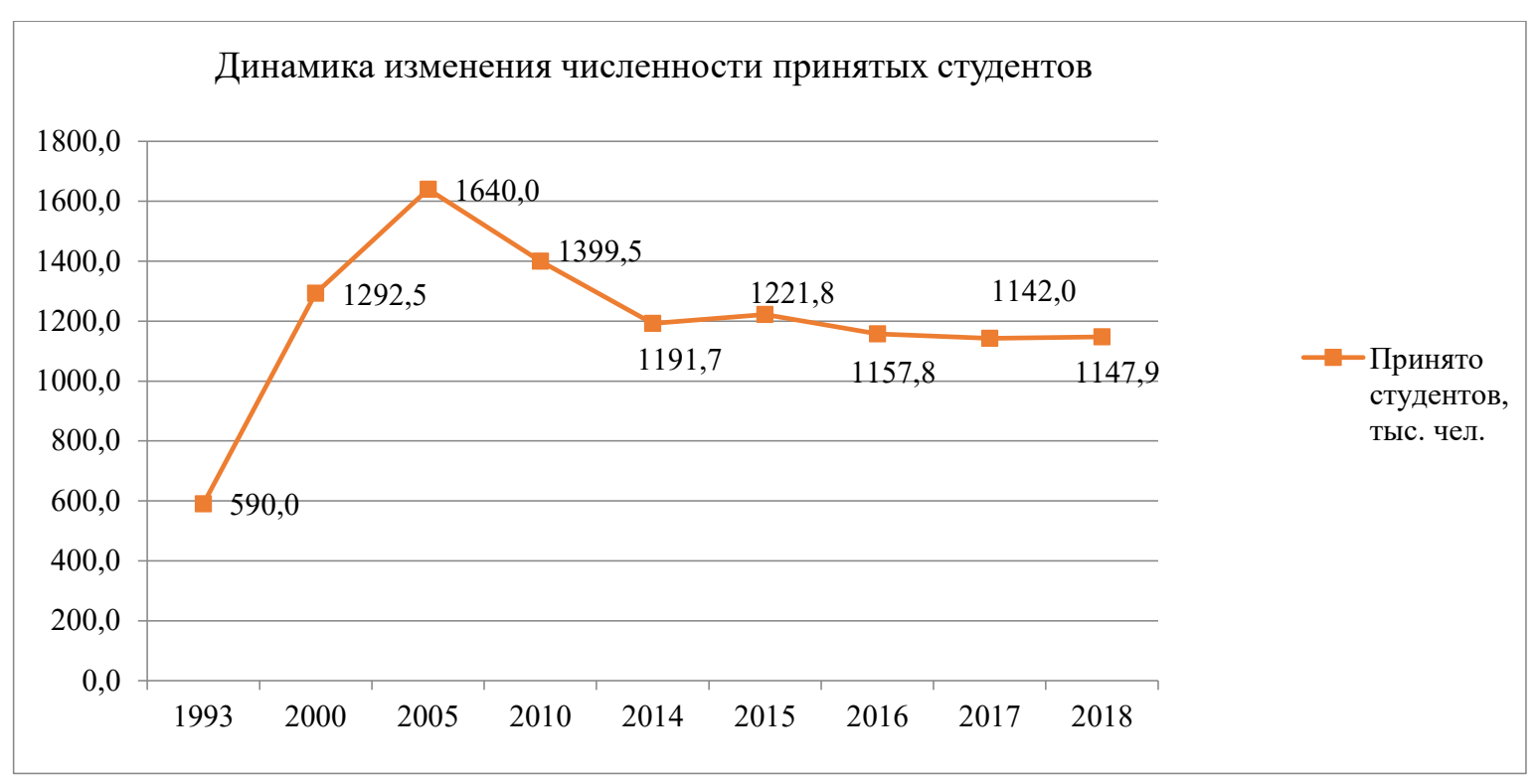

Рисунок 4. Динамика изменения численности принятых студентов, тыс. чел. Выполнено автором

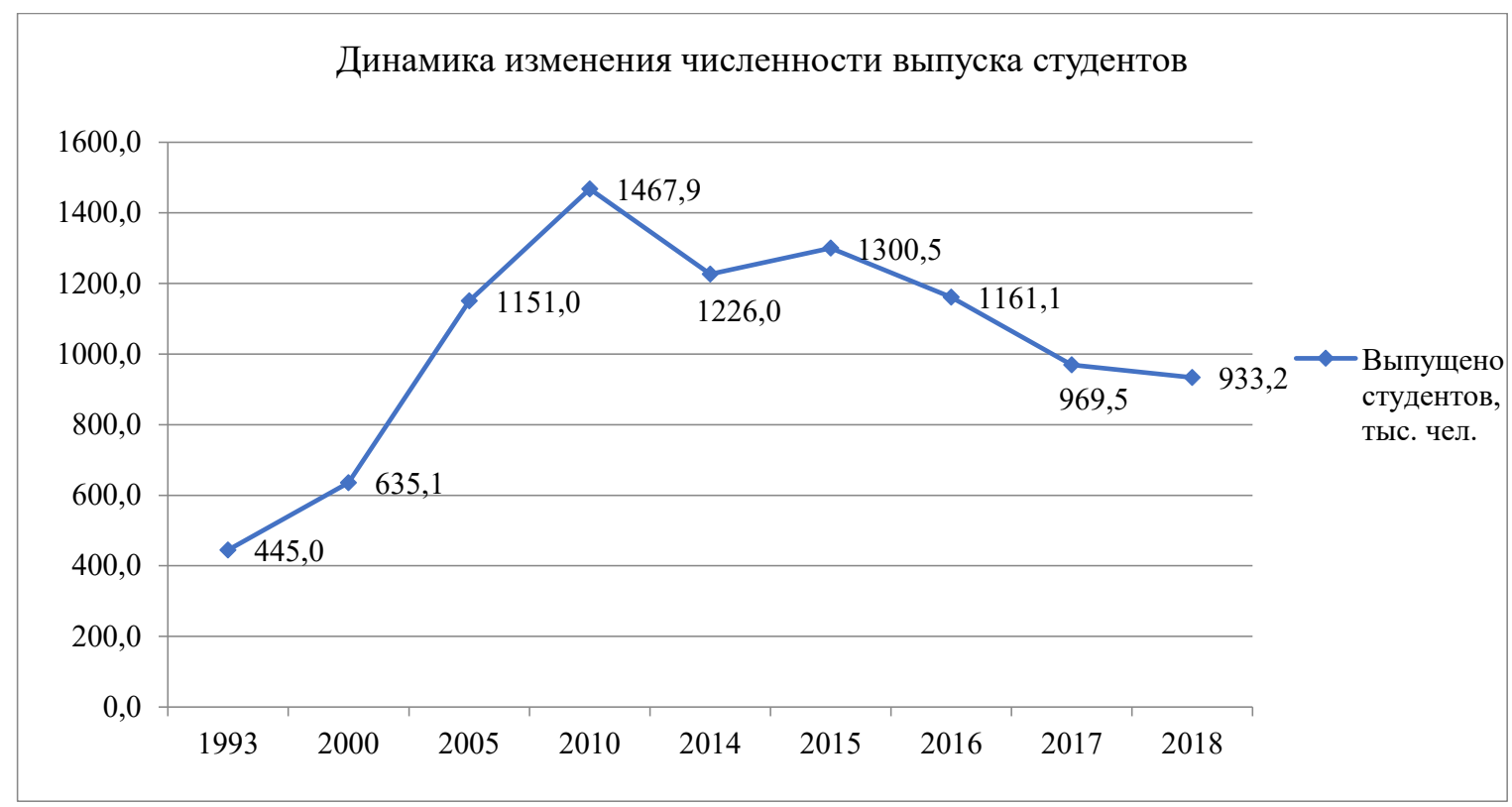

Рисунок 5. Динамика изменения численности выпуска студентов, тыс. чел. Выполнено автором 


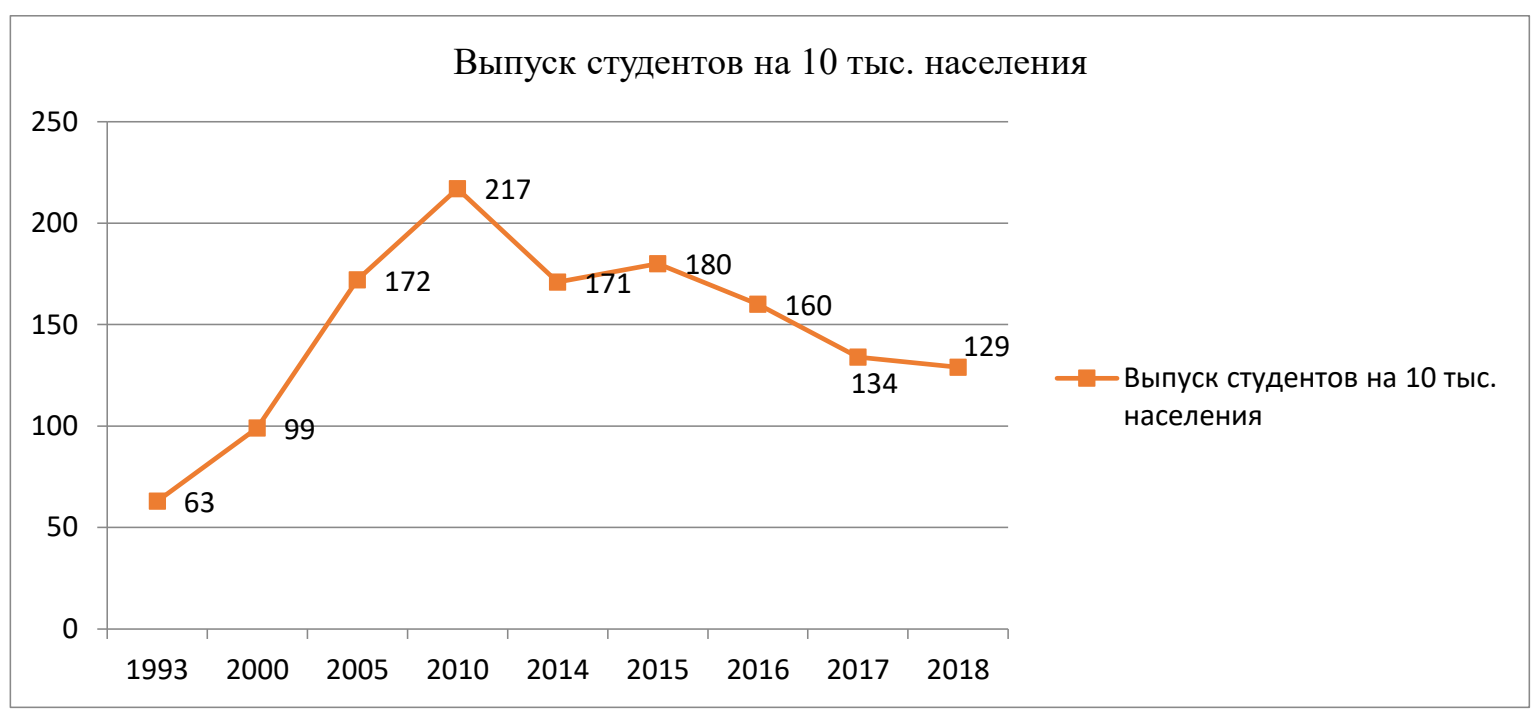

Рисунок 6. Динамика изменения численности выпуска студентов на 10 тыс. населения. Выполнено автором

изменения, направленные на функционирование не только в сегодняшнем, но и завтрашнем дне.

Необходимость развития заключается в том, чтобы обладать набором качеств инновационного характера: рациональностью, гибкостью, быстрой реакцией на изменение рынка труда и внешние эффекты, конкурентоспособностью, эффективностью.

Новые экономические и социальные условия предполагают не адаптацию образовательных организаций к ним, а иное содержательное наполнение всего комплекса образовательных задач, дальнейшую трансформацию системы высшего образования. Так, представляется полезным имеющийся опыт функционирования в ряде учебных заведений системы высшего образования России научно-образовательных и общественных корпораций - НОOК. Корпорации этого уровня становятся движущей силой и стимулами развития, являясь факторами инновационного, социального, экономического, внеэкономического, материального и нематериального характера.

Выводы:

1. В системе высшего образования России, начиная с «нулевых» годов XXI века, произошли серьезные трансформационные изменения. К ним относятся:

- быстрый рост числа вузов и/или филиалов, вплоть до 2010 года;

- резкое снижение количества высших учебных заведений в 2011-2019 годах за счет закрытия филиальной сети, большого количества частных вузов, объединения государственных институтов и университетов;

- усиление требовательности со стороны профильных министерств к той части образовательных организаций и филиальной сети, где был ослаблен контроль за качеством обучения, профессиональной пригодностью ППС и персонала учебных заведений;

- ранжирование на федеральном уровне вузов, по разным категориям (статусам): федеральные, национальные исследовательские, опорные университеты, а также «университет, академия, институт».

2. Система высшего образования, по-прежнему, использует рациональную консервативную составляющую в вопросах стандартного реагирования на имеющиеся проблемы со стороны общества и экономики, нуждающихся в кадрах с соответствующим образованием.

3. Внутри самих организаций высшего образования активизировалась работа по их соответствию требованиям инновационного развития, предусмотренным Ф3 «Об образовании».

4. Вузовский менеджмент трансформируется, стремясь к меньшей схожести с другими учебными заведениями, чем это было в предыдущие годы. Действуя в условиях совершенной конкуренции, вузы ищут новые трансформационные идеи, внедряют изменения, направленные на укрепление социальных, общественных 
и экономических связей вуза с общественными и экономическими институтами.

5. Вузам статуса «университет, академия, институт» и, прежде всего, частным организациям, приходится прилагать значительные организационные и управленческие усилия, чтобы находиться на более-менее равноправных позициях с федеральными, национальными исследовательскими университетами, опорными вузами страны.

6. Конкурентоспособность вуза включает в себя объединение усилий не только внутри учебного заведения и в межвузовском сотрудничестве, но и создание научно-образовательных и общественных корпораций - НООК, деятельность которых включает другие образовательные учреждения, государственно-общественные и общественные объединения.

\section{Библиографический список}

1. Гори, Андре. Нематериальное. Знание, стоимость и капитал. / Пер. М. М. Сокольской; научный ред. М.А. Маяцкий.-М.: Изд. дом ГУ-ВШЭ, 2010.-208 с.

2. Друкер, Питер. Эпоха разрыва: ориентиры для нашего меняющегося общества.- М.: «Вильямс», 2007.C.336.

3. Кириенко С. Россия обладает конкурентными преимуществами для развития креативных индустрий.Официальный сайт информационного агентства ИТАР-ТАСС. - (дата обращения 24.10.2020). - https://tass. ru/obschestvo/9806831

4. Официальный сайт Национального фонда подготовки кадров «Опорные университеты России». - (дата обращения 22.10.2020). - https://flagshipuniversity.ntf.ru/documents

5. Официальный сайт «Я-капиталист».- (дата обращения 05.09.2020). - https://yakapitalist.ru/finansy/skolkov-rossii-vuzov-v-2019g

6. Официальный сайт Росстата (дата обращения 11.10.2020). - http://www.gks.ru

7. Официальный сайт электронной газеты «Вести образования» (дата обращения 16.09.2020).- https:// vogazeta.ru/articles/2019/12/6/quality_of_education/10709-sergey_kravtsov_dopustil_otmenu_akkreditatsii_ vuzov

8. Россия в цифрах. 2019: Крат. стат. сб./Росстат - М., 2019-549 c. http://www.gks.ru

9. Федеральный Закон «Об образовании в Российской Федерации» 29 декабря 2012 года N 273-ФЗ (редакция от 31.07.2020 с изм. и доп., вступ. в силу с 01.09.2020) -.http://www.consultant.ru/document/cons_doc_ LAW_140174/

10. Форсайт Агентства стратегических инициатив «Глобальное образование - 2030.-https://fioco.ru/Contents/ Item/Display/2201455 (дата обращения 15.10.2020).

11. Хаммер, Майкл, Чампи, Джеймс Реинжениринг корпорации: Манифест революции в бизнесе. Пер с англ.: СПб.: Издательство С.-Петербургского университета, 1997. - 332c. 